https://doi.org/10.18485/iipe_euchanges.2021.ch1

\title{
NEW OR POST-ATLANTICISM: EUROPEAN SECURITY IN THE 21ST CENTURY
}

\author{
Richard SAKWA ${ }^{1}$
}

\begin{abstract}
Following the end of the Cold War in 1989-91, the Atlantic power system became the core of a unipolar pattern of world politics and at the same it radicalised. The Atlantic power system rebranded itself as the liberal world order with genuinely universal aspirations, claiming to be the only viable model of modernity. Liberal universalism undermined traditional patterns of sovereign internationalism and diplomacy. The New Atlanticism reinforced the link between democracy and security, norms and power, encouraging democracy promotion and regime change. As the Atlantic power system expanded, the realm of norms was reinforced by the empire of dominion. This rebranded liberal world order claimed to be synonymous with the international system established at Yalta-Potsdam in 1945, a substitution that was to have momentous consequences. This radicalised version of liberal hegemony was 'bound to fail', since its ambitions were so expansive as to classify as delusional, and which in the end provoked domestic and external resistance, notably by Russia. In Europe it meant the suppression of neo-Gaullist aspirations for continental autonomy, although elements of this are now being revived. Although it is still too early to talk about the emergence of a post-Atlantic world, long-term structural changes as well as some more contingent decisional factors are leading in this direction. The resurgence of aspirations for 'strategic autonomy' of a more 'geopolitical' European Union takes place at a time when it is increasingly marginalised geopolitically, and Europe as a whole is more fragmented. This paper examines the dynamics and evolution of post-Cold War Atlanticism, and assesses its future trajectory as the bond between the power system that bears its name and the liberal world order crumbles.
\end{abstract}

Keywords: Atlantic power system, liberal international order, liberal hegemony, Europe, Russia, Eurasia.

${ }^{1}$ Professor, School of Politics and International Relations, Rutherford College, University of Kent. E-mail: R.Sakwa@kent.ac.uk 


\section{INTRODUCTION}

Following the collapse of the Soviet challenge in 1989-91 the Atlantic power system (APS) emerged as the core of a unipolar world order. For the twenty-five years of the cold peace (1989-2014) the APS could claim to be truly universal. Post-communist Russia was in disarray, and in the early years aspired to join the system of which the APS was the core. China, meanwhile, was engaged in its 'quiet rise' as it gathered its economic power and social capacity. The medium powers mostly aligned with the APS, although at the margins some echoes of resistance could still be heard. This was an era of unprecedented Western triumphalism, which included the view that the 'historical West' was the 'winner' of the Cold War. If there were winners, then inevitably there were losers. This represented a radical repudiation of the Gorbachevian view that the end of the Cold War was a common victory establishing the framework for a new and inclusive peace order. Instead, the Atlantic order expanded and deepened, a process defined in this essay as the New Atlanticism (Sakwa, 2015). This combined the military power of the old Atlantic alliance, with the North Atlantic Treaty Organisation (NATO) at its core (dominium) with the normative values of the liberal international order (liberalism). The combination of power and ideology, of dominion and liberalism, represented a new and expansive model of world order, although one with deep roots in the liberal imperialism of the late nineteenth century.

In the cold peace era, the APS underwent a three-fold radicalisation. First, it underwent a name change, although the old name was also used. Thus, the APS rebranded itself as the liberal world order (LIO), also known as liberal hegemony. This included a radical version of globalisation, democracy promotion and regime change. The prohibition on the use of force except with the sanction of the United Nations was weakened, as the leading power in the APS and its allies arrogated the right to decide on the contingent factors allowing intervention. International law thus gave way to the 'rules-based' order, in which rules were interpreted to achieve the goals of the liberal hegemony. This represented a move away from sovereign internationalism towards the validation of humanitarian interventionism, formulated in 2005 as the Responsibility to Protect (R2P). Second, the 'exceptionalist' ideology of the post-Cold War version of the liberal order was accompanied by the politics of expansion rather than the logic of transformation. As the Atlantic power system expanded, the realm of norms was reinforced by the empire of dominion. Third, this rebranded liberal world order claimed to be synonymous with the international system established at Yalta-Potsdam in 
1945 and amended at Helsinki in 1975. This substitution was to have momentous consequences. In Europe it meant the suppression of neoGaullist aspirations for continental autonomy, and globally it entailed claims to universal jurisdiction by a particular regional order.

This radicalised version of liberal hegemony was 'bound to fail' (Mearsheimer, 2019), since its ambitions were so expansive as to classify as delusional (Mearsheimer 2018). Although the intentions may have been good, the results were hubristic, often devastating and in the end provoked domestic and external resistance (Walt 2019). The traditional practices of Atlantic unity are eroding, although military institutionalisation remains firm. The resurgence of aspirations for 'strategic autonomy' of a more 'geopolitical' European Union takes place at a time when it is increasingly marginalised geopolitically, and Europe as a whole is more fragmented. The Trumpian disruption signalled a certain domestic dissatisfaction, although the Trump presidency was unable to deliver on its promise of a strategic rethinking of American foreign and domestic priorities. The election of Joseph Biden in 2020 signalled a return to 'business as normal', but the New Atlanticism was already being undermined. The French foreign minister, Jean-Yves Le Drian, made this explicit in a Europe1 Radio1 interview on 7 November 2020, arguing that there could be no return to a golden age of pre-Trumpian innocence:

We will not return to the status quo ante, to the good old days of the

Trans-Atlantic relationship. The world has moved on after these four years. Europe has emerged from its naïveté. It is beginning to assert itself as a power (cited in Bhadrakumar, 2021).

The Atlantic power system and the liberal hegemony with which it is associated are being challenged by global trends, the emergence of the agenda of 'strategic autonomy' in Europe, as well by an array of fundamental changes, including the emergence of multipolarity (Sakwa, 2017).

This paper examines the dynamics and evolution of post-Cold War Atlanticism, and assesses its future trajectory as the bond between the power system that bears its name and the liberal world order crumbles. Elements of post-Atlanticism are beginning to emerge, although it is too soon to claim that the post-war Atlantic system is in terminal decline.

\section{THE NEW ATLANTICISM}

Classical realist theory suggests that with the end of the Cold War NATO should have been abolished, like its Warsaw Pact counterpart, or at 
least to have quietly withered away. Without the Soviet threat to keep the alliance together, it was assumed that the member states would disperse, and that Europe would take responsibility for its security. At the same time, the countries making up the alliance were undergoing major demographic changes that turned them into multicultural societies that weakened the traditional focus on Atlantic security. Pessimism about the future of the community was justified (Coker, 1997). Instead, following a period of disorientation and a search for an 'out of area' role, the Atlantic power system re-invented itself. The Atlantic community prospered and assumed increasingly ramified features to create a post-Cold War 'New Atlanticism'. This took five main forms.

First, NATO enlarged to encompass most of the new Mediterranean democracies and post-communist countries, and then pushed its way into the Balkans. This was far from uncontested, yet the enlargement drive appeared inexorable and impermeable to political challenge. Poland, Hungary and the Czech Republic joined in March 1999, and then in a 'big bang' enlargement in March 2004 the Baltic republics (Estonia, Latvia and Lithuania), Bulgaria, Romania, Slovakia and Slovenia joined, followed by Albania and Croatia in April 2009, Montenegro in 2017 and North Macedonia in 2020. Despite repeated warnings by Russia that bringing NATO to its borders would be perceived as a first order strategic threat, the Bucharest NATO summit of 2-4 April 2008 promised Georgia and Ukraine eventual membership. The Summit Declaration stressed 'NATO welcomes Ukraine's and Georgia's Euro-Atlantic aspirations for membership in NATO. We agreed today that these countries will become members of NATO'. The Declaration once again affirmed the principles on which the community was based:

Recognising the enduring value of the transatlantic link and of NATO as the essential forum for security consultations between Europe and North America, we reaffirmed our solidarity and cohesion and our commitment to the common vision and shared democratic values embodied in the Washington Treaty. The principle of the indivisibility of Allied security is fundamental (Bucharest Summit, 2008).

Membership Action Plans (MAPs) were deferred because of German and French concerns that encircling Russia would be unnecessarily provocative, yet the strategic direction had been set. Resistance by France and Germany was practical rather than fundamentally political. Although the Declaration talked of 'indivisibility', it had in mind the security of the Atlantic community 
itself. The result of enlargement was precisely to enshrine the divisibility of European security, and thus the new partition of Europe.

There was some genuinely political criticism of the enlargement process. In an interview with Thomas Friedman in 1998, George Kennan, the doyen of international diplomacy and the architect of the original policy of 'containment' of the Soviet Union in the post-war years, was unsparing in his condemnation. Kennan spoke with dismay about the US Senate's ratification of NATO expansion plans:

I think the Russians will react quite adversely and it will affect their policies. I think it is a tragic mistake. There was no reason for this whatsoever. No one was threatening anyone else ... This expansion would make the Founding Fathers of this country turn over in their graves. We have signed on to protect a whole series of countries, even though we have neither the resources nor the intention to do so in any serious way.

Not for the first time the 'superficial and ill-informed' nature of Congressional discussion was condemned. Equally, he adds words that have portent to this day:

I was particularly bothered by the references to Russia as a country dying to attack Western Europe. Don't people understand? Our differences in the cold war were with the Soviet Communist regime. And now we are turning our backs on the very people who mounted the greatest bloodless revolution in history to remove that Soviet regime (Friedman 1998).

Kennan was not alone, and in July 1997 an open letter from senior American statesman to the White House prefigured Kennan's warning that enlargement would be a 'policy error of historic proportions'. They argued that it would be bad for NATO, since it would 'inevitably degrade its ability to carry out its primary mission'; it would be bad for Russia since it would strengthen the non-democratic opposition; it would be bad for Europe since it would "draw a new line of division between the "ins" and "outs" and foster instability'; and it would be bad for America, since it would 'call into question the US commitment to the alliance' (Walker 1997).

Second, NATO became the military arm of liberal hegemony. In the 1990s it intervened militarily in the Balkans, and then in the 2000s it coordinated allied operations in Afghanistan. The liberal universalism of the Clinton presidency dominated the discourse and swept aside realist objections. The idea was that by bringing in the former communist states 
into the 'civilising institutions and prosperity of the West', they would be transformed, just as Germany had been after the war, and that eventually the same would apply to Russia. This was self-contradictory, since NATO's unilateral enlargement alienated Russia, and inhibited the transformative experience that a more inclusive security order may have offered. Russia certainly did not consider itself a defeated power, unlike Germany and Japan after 1945 (cf. Dower, 2000), and instead drew on the 'common victory' principle originally enunciated by Mikhail Gorbachev. Russia considered itself a great power in its own right, unlike the former imperial powers France and Great Britain, which after 1956 effectively accepted their subaltern status within the Atlantic community. Liberal hegemony is a combination of power and norms, and while Russia was ready to accept the norms (hence it joined the Council of Europe and signed up to the Partnership and Cooperation Agreement with the European Union), it was unrealistic to expect it to accept a subaltern status in the new European security order. The US made clear that it was not prepared to share hegemonic leadership, and this in turn rendered the normative transformation of Russia more problematic.

Third, while the emerging security dilemma was clear, there was also a less clearly defined 'normative dilemma'. Atlanticism, both old and new, combines norms and power. This was at the heart of the Atlantic Charter of August 1941 and then incorporated into NATO's founding Washington Treaty in 1949. This gave rise to 'transdemocracy': the view that security and democracy are inseparable. The perspective is formulated in 'democratic peace theory' arguing that democratic states do not go to war with each other. The transdemocratic claim is central to the New Atlanticism. This was welcomed by the former communist countries, and even by many in Russia itself. Security and democracy were the foundations of the post-Cold War order, but this was attended by a growing contradiction between the two arms of the transdemocratic impulse. Tying security and regime transformation into a single package repudiated the pluralism and sovereign democracy that had been recognised at Yalta and become the foundation of the post-war international system. The New Atlanticism was increasingly unable to reflect critically on the geopolitical and power implications of its own actions, a type of geopolitical nihilism that in the end provoked the Ukraine crisis. From a defensive alliance established to resist the Soviet Union, Atlanticism became both more militant in advancing its interests and more culturally aggressive, setting itself up as a model of civilisational achievement. This represented a blow to Russia's self-image as a great power, representing not only a distinctive pole of security but also a country 
with distinctive challenges on the path to some sort of democratic modernity. Transdemocracy moreover, undermined the classical principles of diplomacy, where difference is recognised as legitimate and thus focuses on how to reconcile diversity. Instead, the universalism at the heart of transdemocracy has a homogenising tendency, seeking to ensure all states converge on a single model of modernity.

Fourth, the strategic rationale underlying NATO enlargement is unclear. An alliance system is obviously designed to enhance the security of all of its members, yet the expansion of a security system to the borders of a large neighbouring power with a history of antagonism inevitably created a security dilemma of the highest order. NATO was aware of this, and hence a number of mitigation strategies were adopted. Russia was included in NATO's Partnership for Peace (PfP) programme in 1994, although even then Moscow expressed its dissatisfaction. More was required, and the NATORussia Founding Act on Mutual Relations of May 1997 spoke of a new era:

NATO and Russia do not consider each other as adversaries. They share the goal of overcoming the vestiges of earlier confrontation and competition and of strengthening mutual trust and cooperation. The present Act reaffirms the determination of NATO and Russia to give concrete substance to their shared commitment to build a stable, peaceful and undivided Europe, whole and free, to the benefit of all its peoples. Making this commitment at the highest political level marks the beginning of a fundamentally new relationship between NATO and Russia. They intend to develop, on the basis of common interest, reciprocity and transparency a strong, stable and enduring partnership.

The document defined 'the goals and mechanisms of consultation, cooperation, joint decision-making and joint action that will constitute the core of the mutual relations between NATO and Russia', and argued that 'NATO has undertaken a historic transformation' and insisted that this was a 'process that will continue'. Cooperation was to be achieved through the creation of a new NATO-Russia Permanent Joint Council. NATO committed itself not to place nuclear weapons on the territory of new members, to work on adapting the Conventional Forces in Europe (CFE) treaty to the new realities, and above all 'NATO reiterates that in the current and foreseeable security environment, the Alliance will carry out its collective defence and other missions by ensuring the necessary interoperability, integration, and capability for reinforcement rather than by additional permanent stationing of substantial combat forces' (Founding Act, 1997). 
Although the spirit of the Founding Act was cooperative, in institutional terms it was declaratory than substantive, and left Russia isolated vis-à-vis other NATO members. This is why, in the wake of the 9/11 attack on the US and Russia's support in what was to become the 'war on terror', the decision was taken to go further. On 28 May 2002 the NATO-Russia Council (NRC) was established at the NATO-Russia summit in Rome as 'a mechanism for consultation, consensus-building, cooperation, joint decision and joint action in which the individual NATO member states and Russia work as equal partners on a wide spectrum of security issues of common interest' (NATO 2002). Russia's status was enhanced from one against the others to what was intended to be a higher degree of partnership, although the text studiously avoided allowing Russia a 'veto' in any shape or form on NATO-centred security issues (Nato-Russia Council, 2002). In the event, at moments of crisis the NRC failed to become a forum for conflict resolution, isolating rather than engaging Russia. America vetoed convening the NRC to discuss the Georgia crisis in 2008, a move which it later admitted was a mistake; but once again as the Ukraine crisis unrolled in 2014, on 1 April NATO suspended 'all practical civilian and military cooperation between NATO and Russia', although contacts at ambassadorial level were allowed (Statement, 2014). The institutional architecture of cooperation, despite the aspirations of both sides, was inadequate to meet the real challenges of European security in the twenty-first century. The various Foundational statements and Partnership bodies were mitigation measures, intended to blunt the edges of the onward enlargement of the Atlantic power system. Equally, they were no more than sticking plaster disguising the fundamental process at work, namely over-balancing against a putative Russian threat. It was understandable that the former Soviet bloc countries would have concerns about a revival of Russian imperialism, but balancing strategies were not necessarily the most rational response.

This takes us to the fifth and final point, namely the way that the New Atlanticism made explicit what in the Cold War era had been latent, namely the fact that European integration developed within the constraints of Atlanticism, what Glenn Diesen calls 'inter-democracy'. With the end of the Cold War, there was much talk of the 'hour of Europe' yet misguided and inept interventions in the Balkans revealed the limited instruments at the EU's disposal, and the pre-eminence of the conflicting interests of its member states in the region. In the end, it was the US that took the lead in bringing the Bosnian war to an end in 1995, and which led the assault against Serbia in 1999. The EU's Common Foreign and Security Policy (CFSP) since the Treaty of Lisbon (the 'Reform Treaty') of 13 December 2007 effectively 
became part of the Atlantic system. ${ }^{2}$ Accession countries are now required to align their defence and security policy with that of NATO, resulting in the effective 'militarisation' of the EU. A number of clauses in the Association Agreement between the EU and Ukraine, which was due to have been signed in Vilnius on 28-29 November 2013 but which in the end were signed only in May 2014 after the overthrow of President Viktor Yanukovych, testified to the growing 'transdemocratic' linkage between security and politics. Article 4 speaks of the Aims of Political Dialogue, with section 1 stressing that ${ }^{\prime}$ Political dialogue on all areas of mutual interest shall be further developed and strengthened between the Parties. This will promote gradual convergence on foreign and security matters with the aim of Ukraine's ever deeper involvement into the European security area'. Article 7.1 called for EU-Ukrainian convergence in foreign affairs, security and defence. As if this was not explicit enough, Article 10 on Conflict Prevention, Crisis Management and Military-Technological Cooperation noted in section 3 that 'The parties shall explore the potential of military and technological cooperation. Ukraine and the European Defence Agency (EDA) will establish close contacts to discuss military capability improvement, including technological issues'.

\section{CONSEQUENCES OF THE NEW ATLANTICISM}

The main consequence of New Atlanticism is resistance from Russia and the renewed division of Europe. From the very beginning Russia chafed at the Atlanticist definition of the post-Cold War order, which by definition excluded a continental dimension in which Russia would be a natural equal. The country's weakness in the 1990s allowed only impotent growls over Kosovo, NATO enlargement and other issues. However, in the 2000s Russia recovered from its immediate post-communist disorder and was now in a position to reinforce its complaints with action. However, even with the renewed state capacity, Vladimir Putin tried to find some middle path

\footnotetext{
${ }^{2}$ The Lisbon Treaty was careful to stress the development of a common European security and defence policy (Section 2, 'Provisions on the Common Security and Defence Policy', Articles 42 to 46), but stressed that this would be compatible with the existing obligations of member states to NATO (Article 42.2): Consolidated Versions of the Treaty on European Union and the Treaty on the Functioning of the European Union (Luxembourg, European Union, 2010); http:/ / europa.eu/lisbon _treaty/full_text/.
} 
between the relatively uncritical Atlanticism associated with foreign minister Andrei Kozyrev in the first period of Russian foreign policy in the early 1990s, and then the rather harsh anti-Atlanticism pursued by foreign and then prime minister Evgeny Primakov in the second part of the decade. This classic Putinite strategy of reconciling extremes was new realist: it was realist to the degree that it eschewed what was perceived to be the excessive idealism of the liberal period in the early 1990s; and it was new because of its repudiation of Primakov's revival of neo-Khrushchevite ideas of peaceful coexistence between two fundamentally opposed system. Instead, Putin believed that a more progressive and rational model of interaction with the Atlantic power system could be found.

However, following numerous rebuffs, including the invasion of Iraq and destruction of Libya, plans to install a ballistic missile defence (BMD) system in Poland and the Czech Republic (later revised to a phased system in Romania and Poland), and the inexorable march of NATO to Russia's borders (including the promise of ultimate membership of Georgia and Ukraine), when Putin returned to the Kremlin in 2012 for his third presidential term a new era in Russian foreign policy was inaugurated. Neorevisionism does not repudiate the normative framework of international society as it has developed since 1945, but it does repudiate the practices of the Atlantic power system as practiced since 1989. This entails the acceleration of Eurasian integration efforts, giving rise to the creation of the Eurasian Economic Union in 2015. It means cultural and political resistance to transdemocracy, which in the end precipitated the conflict in Ukraine in 2013-14. Neo-revisionism does not mean the reconstitution of a 'Russian empire' or even the Soviet Union, but it does assert historical and political pluralism and sovereign internationalism. The Second Cold War is as much about alternative models of world order as it is about the character of particular systems.

The New Atlanticism failed to generate a genuinely post-Cold War pancontinental security and developmental model, and thus in the end reproduced the Cold War. The idea that NATO enlargement would help put an end to the division of Europe discounted the fact that Europe's largest country remained a growling and increasingly dissatisfied external presence. By satisfying the perceived security needs of one constituency (the post-communist states), the security concerns of a nuclear-armed major state were ignored (Hill, 2018). The creation of new dividing lines in Europe diminished the security of all. When Russia did finally respond in the manner anticipated by Kennan and other critics, it was taken as justification 
of the need for NATO consolidation, thus becoming a self-fulfilling prophecy. European security became increasingly militarised as a new Iron Curtain began to be built across Europe, now running from Narva on the Baltic to Mariupol on the Sea of Azov. The New Atlanticism represented a response to the changed conditions of the post-Cold War era, yet failed to generate a larger strategic rethinking of how European, and thereby global, security could be enhanced.

The New Atlanticism's changed functionality shaped its internal evolution. Two outstanding features can be identified: its hermetic and allencompassing character. The notion of hermetic here means that despite the changed security situation after 1989-91 and enlargement to encompass most Soviet bloc states and even part of the former Soviet Union (the Baltic states), its internal rationale and structures remained remarkably impervious to change. The Atlantic alliance was always a combination of norms and power, but this episteme in the post-Cold War era shifted from the rational ideational foundations of a security order to become more of an ideological project. Ideologies, as we know, tend to lose flexibility and pragmatism and become more rigid. They lose the ability to devise innovative and flexible policy responses and become more selective in understanding complex information flows. Dogmatism takes the place of dialogue. The view that NATO enlargement may actually undermine the stated goal of enhancing the security of its members is dismissed as subversive and even irrational. The idea of some sort of pan-European security order no longer fits into the Overton window of acceptable discourse. Concessions to Russia are considered weakness if not appeasement (Blank 2014). The idea of a multipolar world order is considered anathema to the New Atlanticists because it undermines the universality of liberal hegemony. In sum, there was little ideational or institutional innovation at the end of the Cold War, and instead the ideological and corporate mentalities of the Cold War were reinforced.

As for New Atlanticism's comprehensive character, this gained in intensity as the foreign and security dimension of the EU effectively merged with the Atlantic power system (for an example, see Atlantic Council, 2020). EU enlargement has become part of a broader process of the expansion of the Euro-Atlantic community, in which security, good governance and economic reform go hand in hand. For historical reasons a number of EU countries are not members of NATO - Austria, Cyprus, Ireland, Finland, Malta and Sweden - but since 1989 most new members of the EU have also become members of NATO. Even this neutrality is being questioned, with Atlanticists 
in both Sweden and Finland now arguing in favour of NATO membership. Overall, post-Cold War Atlanticism reflects the evolution of the Atlantic security system into a total community, encompassing not only security but also a specific representation of a hybrid Euro-Atlantic civilisation. This means the tempering of certain traditional European values, such as social justice and equality, but above all the effective repudiation of neo-Gaullist ideas about pan-continental unity and autonomy.

The New Atlanticism stymied the development of alternative models of European security. In the early period Russia expressed hopes that the Organisation for Security and Cooperation in Europe (OSCE) would become the main continental security body. The advantages were clear: Russia would be a founder member and enjoy veto powers. There was talk even of creating a European security council based on the OSCE, analogous to that operating in the UN, to allow the major powers to stake a claim to the management of pan-continental security issues on a parity basis. The idea was rejected, and instead it was NATO that remained predominant, with all of the attendant problems outlined above. In a final attempt to break the impasse, in June 2008 President Dmitry Medvedev suggested a new European Security Treaty, but the idea was again effectively quashed (Weitz, 2012). The hermetic and comprehensive character of the Atlantic community was reinforced, a process that culminated in 2014 when the cold peace gave way to the return of a full-blown new Cold War.

\section{TOWARDS POST-ATLANTICISM?}

However, the Second Cold War differs from the first in several significant ways. The regional, ideological and security context differs from the first, but above all the coherence of the Atlantic power system is challenged in new ways. We are beginning to see the outlines of what postAtlanticism could look like.

First, already in the Barack Obama presidency the character of US leadership in the Atlantic region, and globally as well, was questioned. The global financial crisis from 2008 battered US institutions and prompted calls for retrenchment. However, this provoked a vigorous re-assertion of New Atlanticist orthodoxy from the defenders of liberal hegemony. The perennial issue of greater burden-sharing was articulated not only in the form of the European NATO states paying more for their defence, but also that they should take greater responsibility for their own security. Obama was the first post-war American president to focus less on Europe than on East Asia, 
and in particular the growing power of China. This took the form of Hillary Clinton's 'pivot to the East', which entailed reinforcing America's security presence in the region (establishing a new base in Australia and consolidating its existing alliance network); trying to entice India into some sort of quasi-alliance framework, articulated in the form of an Indo-Pacific regional orientation (rather than the old Asia-Pacific formulation); the creation of an economic community that excluded China, the Trans-Pacific Partnership agreement (TPP); and the beginning of various neo-containment strategies against China itself.

Second, the Trumpian disruption represents a stark version of postAtlanticism. As with Russia's unexpected defection from the Soviet Union in the late 1980s, so under Trump the core of the alliance system appeared ready to defect from the periphery. Trump's version of 'America First' returned to some of the concerns of so-called isolationists in the inter-war period - although in fact, most were not isolationist in any real sense, but cleaved to the traditional version of internationalism, in which sovereign states engage with each other without the penumbra of norms, a transformative agenda or a ramified and permanent alliance system (Wertheim 2020). To this mix Trump added a harsh mercantilism, which repudiated the post-Cold War globalisation view that intensified economic interactions between states would benefit them all. As the global pie grew, all would have a larger portion. Instead, Trump's approach returned to Physiocratic notions that the gain of one would be to the detriment of the other. Trump applied this to repudiate the Transatlantic Trade and Investment Partnership (TTIP) as well as to the renegotiation of the NAFTA agreement with Canada and Mexico. It was also applied to relations with the EU and above all China. Above all, Trump saw little value in the American alliance system and multilateral institutions in general. During his election campaign in 2016 he argued that NATO was 'obsolete', although once in office he failed to organise a serious strategic review of the issue. Trump was particularly hostile to the EU, which he saw as a cartel that stymied the free operation of American capital. Once again, he had a point, but his formulation was disruptive without a compensating positive agenda. Equally, Trump's endorsement of some of the illiberal resistance to EU norms, in particular by Hungary and Poland, disrupted EU solidarity. In short, Trump provided an intimation of what one model of post-Atlanticism might look like. This represents the negative transcendence of Atlanticism, entailing the reversion to an anarchic and competitive system accompanied by great power conflict and competition unregulated by multilateral institutions and norms. 
The third route to post-Atlanticism is the divergence between its two wings. In the cold peace years the EU created several instruments to manage foreign policy and to endow it with greater 'actorness' in international affairs. This includes appointing a President of the European Council and creating the European External Action Service, whose head is a vice president of the European Council. The technocratic role of the European Commission was thereby reinforced, although its President remains a powerful actor in European foreign policy. The EU Global Strategy (EUGS) of June 2016 gave voice to aspirations for greater 'strategic autonomy', based on an emerging ideology of 'principled pragmatism' (European Union, 2016. There were also hesitant moves towards endowing the EU with some military capacity, although always couched in terms of not infringing NATO's prerogatives (Scazzieri, 2020). The onset of the Second Cold War and elements of estrangement from Trumpian America prompted the new President, Ursula van der Leyen, in 2019 to talk about creating a 'more geopolitical' European Commission. After seven years of negotiation, in December 2020 the EU and China agreed in principle on a Comprehensive Agreement on Investment (CAI), much to Washington's displeasure. Already several EU countries had signed up to China's Belt and Road Initiative, and the 17+1 formula linked China with many south-eastern EU members and aspirants. The Trumpian disruption reinforced an understanding among European leaders that the old days of uncritical interdependence with the US were over, even though Trump's successor, Joseph Biden, restored normal diplomatic intercourse between the two regions. The deeper trend was towards the greater articulation of the EU as a distinct security and foreign policy actor, although remaining within the carapace of the Atlantic power system. However, in the long run the outsourcing of security to an external actor would become increasingly less viable if the EU wished to remain an independent actor in international affairs.

Four, the Covid-19 pandemic from 2020 accelerated a process that had already long been in train, namely the 'renationalisation' of security by member states. A number of countries resisted spending more on defence. Even those who met the two per cent target set by the Wales NATO summit in 2014, like the UK, continued to reduce the number of personnel under arms. Equally, Turkey remains an awkward partner, even from the military perspective. Allied forces were not allowed to use Turkish bases to invade Iraq in 2003, and Turkish airfields could not be used to support the AngloAmerican bombing campaign against Islamic State in Syria from 2014. Bloc discipline began to loosen, with Greece, Turkey and the Republic of Cyprus coming into conflict over energy resources in the Eastern Mediterranean. 
This is accompanied by the continued narrative of European abandonment. This was expressed most forcefully by Polish foreign minister Radek Sikorski. In a leaked conversation between Sikorski and the former Polish finance minister Jacek Rostowski in April 2014, published in the Polish magazine Wprost on 23 June, the foreign minister warned that 'The PolishAmerican alliance is not worth anything: it's even damaging, because it creates a false sense of security for Poland', suggesting that Washington had been too weak in the conflict with Russia (Smith 2014). In keeping with the spirit of that conversation, in the Trump era Poland sought bilateral security guarantees with the US.

A fifth indicator of the emergence of a post-Atlantic era would be the loss of popular support for the old alliance system. In the Cold War years there was a clear and present danger in the form of Warsaw Pact armies East of the Elbe, and although there were ups and down in the level of popular support, as well as a vigorous peace movement in the 1980s warning against nuclear escalation, overall popular support and bloc discipline held. However, in the post-Cold War era the rationale for such a ramified security and political system is harder to justify. The emergence of Russia as the bogeyman of course helped reinforce support. NATO needs an enemy to survive, and the image of the enemy was revived to ensure the alliance's continuation. A fatal syllogism emerged, whereby NATO was justified by the need to deal with security threats created by its own existence. The popular base for the New Atlanticism is inevitably more brittle than during the original Cold War. Even in Germany, where the modern state was created by the Cold War, the strong showing for left and right 'populist' parties suggests a growing mood of Atlantic-scepticism. This is countered by a growing elite consensus against Germany's traditional role as the 'honest broker' between Russia and Europe, a type of neoBismarckianism that helped Germany first accept and then transcend the Cold War through Ostpolitik and the broader policy of détente.

A sixth potential danger to New Atlanticist hegemony is the problem of double standards, the perceived or real gulf between normative declarations and political practices. As noted, the NATO alliance is a security community based on the combination of values and power, norms and dominion. The danger is that the gulf between the two could widen beyond acceptable limits. Already Russian minorities in Estonia and Latvia have legitimate grievances about the lack of automatic citizenship rights. In Turkey, Hungary and Poland some fundamental principles enshrined in the European Convention on Human Rights are being eroded, with the 
commitment to effective constraints on the executive, the independence of the judiciary, and the accountability of the political class and the bureaucracy being undermined. The American system of extraordinary rendition, in which individuals were captured or kidnapped and then sent across the world in secret flights to torture and interrogation centres, involved a number of alliance members. The US Senate report on the CIA's interrogation and detention programme provides shocking information about the degree of brutality associated with the programme (Senate Select Committee, 2014). It found that torture 'regularly resulted in fabricated information', as noted by the committee chair Diane Feinstein, who went on to call the torture programme 'a stain on our values and on our history' (Ackerman and Borger, 2014, p. 1). At least 54 countries cooperated with the rendition activities, of which 17 were or were soon to become members of the EU. Some Eastern European countries hosted US 'black sites' (torture facilities) that are now members of the EU, notably Lithuania, Poland and Romania, while the UK was actively involved in facilitating rendition flights.

Seventh, NATO and EU attempts to counter Russian 'disinformation' revived Cold War patterns of propaganda and political warfare (Rid, 2020). One example demonstrates the slippery terrain on which this battle is waged. The 'ecosystem' metaphor was at the heart of the State Department's Global Engagement Centre (GEC) report issued on 5 August 2020. GEC describes itself as 'the US government's dedicated centre for countering foreign disinformation and propaganda'. It analysed supposed Russian proxies peddling policies critical of US policies, but demonstrated how the war against Russian disinformation rendered such material not part of a normal debate and pluralism of views but as 'muddying the waters of the information environment in order to confuse those trying to discern the truth'. The fundamental argument was that 'Russia has operationalized the concept of perpetual adversarial competition in the information environment by encouraging the development of a disinformation and propaganda ecosystem that allows for varied and overlapping approaches that reinforce each other even when individual messages within the system appear contradictory'. The Kremlin was condemned for bearing 'direct responsibility for cultivating these tactics and platforms as part of its approach to using information as a weapon'. The concept of 'disinformation' was defined broadly, encompassing anything published by an alleged Russia-friendly source, whether true or not, and if it contradicted another item, that only revealed how cunning Moscow was in pushing 'multiple versions' of stories to confuse the public. By definition, anything associated with Russia was tainted; and by the same token, anything practiced by the US and its allies 
was virtuous. Thus the Kremlin was condemned for the 'weaponisation of social media' and 'cyber-enabled disinformation' as 'part of its approach to using information as a weapon', as if these phenomena were not part of the contemporary media environment. Moscow was accused of investing 'massively in its propaganda channels, its intelligence services and its proxies to conduct malicious cyber activity to support their disinformation efforts' (US Department of State, 2020).

Eight, the attempt to render a contingent security alliance created under one set of circumstances into something more universal and enduring inevitably stimulated resistance. We have noted how Russia became neorevisionist, challenging not the principles of the current international system but the claims of the Atlantic power system to represent the only viable model of European security and norms. However, there are broader processes at work. Some of these are political, notably the creation of a set of 'post-Western' anti-hegemonic institutions such as the BRICS association as well as the Shanghai Cooperation Organisation. There are also long-term geo-economic shifts, as the centre of economic gravity moves to the Pacific basin, and China emerges as a credible peer competitor to the US. A new pattern in global politics is beginning to emerge and the much-anticipated multipolarity is finally taking shape.

Finally, and perhaps most significant in the long-term, the greater Eurasian region is beginning to consolidate. Russia is devising a heartland strategy of its own, to overcome the danger of the country becoming a dual periphery (to Western Europe and East Asia), and this includes alignment with China while keeping the door open to the West. If greater Eurasia becomes a dynamic developmental hub (and in the long-term there is no reason to suppose that this will not be the case), then Western Europe will become a periphery to the new heartland, and at the same time increasingly irrelevant to the US (as Trump already indicated). Equally, as multipolarity takes shape, the New Atlanticist unipolar model will become increasingly anachronistic, and erode the US-EU partnership. The land powers of Asia (although they will also once again take to the seas) will finally overcome the 500-year predominance of the traditional maritime powers, and the New Atlanticism will give way to a post-Atlantic era.

\section{CONCLUSION}

One of the most surprising features of the post-Cold War world is the continued existence of NATO. After all, it had achieved its purpose - 
containing the USSR - and even more, it witnessed the demise of its erstwhile foe. Realist IR theory has few explanations for the continued existence of a defensive alliance after the object of its existence had gone. Liberal theory, on the other hand, is more forthcoming with explanations for NATO's continued existence. NATO had always been a dual body: a defensive military alliance; as well as a community of values, as outlined in the Atlantic Charter in 1941, and then in the founding treaty of NATO in 1949. In that capacity, the alliance was about more than security but also concerned with defending a particular way of life. This would have been relatively unproblematic if some sort of substantive security relationship had been established with post-communist Russia. Instead, the failure to incorporate Russia intensified the contradiction between norms and dominion within the Atlantic power system.

From its inception in the wake of the First World War, its reinvention in 1941 as the US prepared to enter the war against Nazi Germany and then codified in Cold War conditions in 1949, and on to the New Atlanticism after 1989, the idea of a Euro-Atlantic security community based on a unique combination of values and power, norms and dominion has shaped the destiny of Europe. The New Atlanticism represented a radicalisation of Atlanticism, but the failure to incorporate Russia revived classic Cold War patterns on the continent. However, the Second Cold War is no mere repetition of the first, and some fundamentally new dynamics are at work. Although there is no imminent prospect for the demise of the Atlantic power system, certain pressures are beginning to tear at its coherence. The New Atlanticism represented the apogee of this order, but its radicalisation in the post-Cold War era sowed the seeds of its own destruction. The failure to incorporate Russia into a transformed security and developmental community provided incentives to advance Eurasian strategies of its own, now reinforced by the enormous and growing power of China.

This paper has identified the main features of the New Atlanticism, and examined some of the issues that could herald the onset of post-Atlanticism. The analysis provides a framework for analysis of the security and normative challenges facing Europe and the world.

\section{REFERENCES}

Ackerman, S. and J. Borger (2014, December 10). 'Torture: The Stain on America', Guardian, retrieved from https:/ / www.theguardian.com/us- 
news/2014/dec/09/cia-torture-report-released. Accessed 14 January 2021.

Atlantic Council (2020). NATO20/2020: Twenty Bold Ideas to Reimagine the Alliance After the 2020 Election, editor in chief Christopher Skaluba. Scowcroft Center for Strategy and Security. New York.

Bhadrakumar, M. K. (2021, January 12). 'Germany Draws Another Line in the Sand for the US', retrieved from https://indianpunchline.com/ germany-draws-another-line-in-the-sand-for-the-us/. Accessed 12 January 2021.

Blank, S. (2014, December 28). 'Russia's Vladimir Putin Clearly Wants to Dominate all of Europe', Washington Post, retrieved from https:// www.washingtontimes.com/news/2014/dec/28/stephen-blankvladimir-putin-ukraine-objective-is-/ Accessed 2 January 2021.

Coker, C. (1997). Twilight of the West. Boulder, CO, Westview Press.

Dower, J. W. (2000). Embracing Defeat: Japan in the Wake of World War II. New York, Norton

European Union (2016, June). Shared Vision: Common Action: A Stronger Europe. A Global Strategy for the European Union's Foreign and Security Policy, retrieved from http://europa.eu/globalstrategy/en. Accessed 12 December 2020.

Friedman, T. (1998, May 2). 'Foreign affairs; now a word from X', New York Times, retrieved from https://www.nytimes.com/1998/05/02/opinion / foreign-affairs-now-a-word-from-x.html. Accessed 12 January 2021.

Hill, W. H. (2018). No Place for Russia: European Security Institutions since 1989. New York, Columbia University Press.

Mearsheimer, J. J. (2018). The Great Delusion: Liberal Dreams and International Realities. London and New Haven, CT, Yale University Press.

Mearsheimer, J. J. (2019). 'Bound to Fail: The Rise and Fall of the Liberal International Order', International Security, 43 (4), pp. 7-50.

NATO (1997 May 27). ‘Founding Act on Mutual Relations, Cooperation and Security Between NATO and the Russian Federation', retrieved from http://www.nato.int/cps/en/natohq/official_texts_25468.htm. Accessed 2 January 2019.

NATO (2002). About, retrieved from http://www.nato.int/nrc-website/ en/about/index.html. Accessed 12 January 2021. 
NATO (2008, April 3). 'Bucharest Summit Declaration', retrieved from http://www.nato.int/cps/en/natolive/official_texts_8443.htm Accessed 12 January 2021.

NATO (2014, April 01). 'Statement by NATO Foreign Ministers', retrieved from http:/ / www.nato.int/nrc-website/en/articles/20140327-announcement/index.html. Accessed 12 January 2021.

Nato-Russia Council (2002 May 28). 'Rome Declaration', retrieved from http:// www.nato.int/nrc-website/media/59487/2002.05.28_nrc_ rome_declaration.pdf, Accessed 12 January 2021.

Rid, T. (2020). Active Measures: The Secret History of Disinformation and Political Warfare. London, Profile Books.

Sakwa, R. (2015). The New Atlanticism, Valdai Paper No. 17 (Moscow, Valdai Club, May 2015); http://www.scribd.com/doc/266515275/The-NewAtlanticism. The Russian version is Noryi Atlantizm; http:// www.scribd.com/doc/266515505/Новый-Атлантизм. Reprinted as 'The New Atlanticism', Russia in Global Affairs, special issue, JulySeptember 2015, pp. 99-109, http://eng.globalaffairs.ru/number/TheNew-Atlanticism-17695.

Sakwa, R. (2017). Russia against the Rest: The Post-Cold War Crisis of World Order. Cambridge, Cambridge University Press.

Scazzieri, L. (2020, September 30). 'Can the EU's Strategic Compass Steer European Defence?', Centre for European Reform, retrieved from https://www.cer.eu/publications/archive/bulletin-article/2020/caneus-strategic-compass-steer-european-defence. Accessed 12 October 2020.

Senate Select Committee on Intelligence (2014). Committee Study of the Central Intelligence Agency's Detention and Interrogation Program, retrieved from http://www.intelligence.senate.gov/study2014/ sscistudy1.pdf, Accessed 12 January 2021.

Smith, B. 2014. 'Polish Foreign Minister: we Gave the US a "Blowjob" and Got Nothing', BuzzFeed, 22 June; retrieved from http://www.buzz feed.com/bensmith/polish-foreign-minister-we-gave-the-us-a-blowjobgot-nothing. Accessed 12 January 2021.

US Department of State. (2020, August). Pillars of Russia's Disinformation and Propaganda Ecosystem, GEC Special Report, retrieved from https:// content.govdelivery.com/attachments/USSTATEBPA/2020/08/05/fil e_attachments/1512230/Pillars\%20of\%20Russias\%20Disinformation $\% 2$ 
0and \% 20Propaganda \% 20Ecosystem_08-04-20\%20\%281\%29.pdf. Accessed 12 September 2020.

Walker, M. (1997, July 4). 'Cold Warrior Foils Warning about NATO', Moscow Times

Walt, S. M. The Hell of Good Intentions: America's Foreign Policy Elite and the Decline of US Primacy. New York, Farrar, Straus, and Giroux.

Weitz, R. (2012). The Rise and Fall of Medvedev's Security Treaty. German Marshall Fund of the United States.

Wertheim, S. (2020). Tomorrow the World: The Birth of US Global Supremacy. Harvard, Belknap Press.

NATO-Russia Founding Act on Mutual Relations of May 1997 